Brazilian Journal

of Chemical

Engineering

ISSN 0104-6632

Printed in Brazil

Vol. 19, No. 02, pp. 151 - 158, April - June 2002

\title{
PHENOL REMOVAL THROUGH COMBINED BIOLOGICAL AND ENZYMATIC TREATMENTS
}

\author{
J.V.Bevilaqua ${ }^{1}$, M.C.Cammarota ${ }^{2}$, D.M.G.Freire ${ }^{3^{*}}$, and G.L.Sant'Anna Jr. \\ ${ }^{1}$ Chemical Engineering Program/COPPE, Federal University of Rio de Janeiro - RJ, Brazil. \\ ${ }^{2}$ School of Chemistry, Federal University of Rio de Janeiro - RJ, Brazil. \\ ${ }^{3}$ Chemistry Institute, Federal University of Rio de Janeiro, Centro de Tecnologia (CT), \\ Fone (021) 2562-7360, Av. Brigadeiro Trompowski, s/n, Bloco A, sala 549-2, CEP 21945-900, \\ Cidade Universitária, Ilha do Fundão, Rio de Janeiro - RJ, Brazil.
}

(Received: February 10, 2002 ; Accepted: April 17, 2002)

\begin{abstract}
This work studies the use of biological and combined biological/enzymatic treatments in phenol degradation. The systems studied were conventional batch aerobic biological followed or preceded by enzymatic treatment. Tyrosinase extracted from the mushroom Agaricus bispora was employed.

Biological treatment efficiently degraded effluents containing up to $420 \mathrm{mg} \cdot \mathrm{L}^{-1}$ of phenol, removing $97 \%$ of the COD and $99 \%$ of the phenol in 48 -hour batches. Alterations in phenol concentration intake reduced treatment efficiency significantly. Enzymatic polishing of biotreated effluent removed up to $75 \%$ of the remaining phenol in a four-hour reaction with $46 \mathrm{U} \cdot \mathrm{mL}^{-1}$ of tyrosinase and $50 \mathrm{mg} \cdot \mathrm{L}^{-1}$ of chitosan (used as coagulant). Enzymatic pretreatment with $20{\mathrm{U} . \mathrm{mL}^{-1}}$ of tyrosinase reduced the phenol concentration by $25 \%$ after 2 hours of reaction, although initial COD increased up to 58\%. The subsequent biological treatment of that enzymatic pretreated effluent reduced COD to $151 \mathrm{mgO}_{2} \cdot \mathrm{L}^{-1}$ and phenol concentration to $1 \mathrm{mg} . \mathrm{L}^{-1}$ in $24-$ hours batches.

Keywords: tyrosinase, phenol removal, biological treatment.
\end{abstract}

\section{INTRODUCTION}

Phenol is a major pollutant present in the wastewaters from several industrial activities: coal mining, petrol refining, pharmaceutical production, founding and steel and iron manufacture, and the tanning and finishing of leather (U.S.EPA, 1980). Commonly used conventional treatments (biological, chemical oxidation and adsorption) often fail to generate final effluents with the required discharge quality at affordable costs. Considering that in Brazil legal discharge limit for phenol is $0.5 \mathrm{mg} . \mathrm{L}^{-1}$, the importance of developing treatment technologies that achieve this limit must be emphasized (CONAMA, 1991).

In the last two decades, several researchers have studied the use of enzymes in wastewater treatment (Karam and Nicel, 1997). Enzymes have many potential advantages over conventional biological treatment and/or chemical oxidation: the lack of an acclimatization period, the absence of problems related to charge shocks or toxic effects, and no generation of unexpected products due to their high specificity.

Tyrosinase (also known as polyphenoloxidase; EC 1.14.18.1) is involved in the phenomenon of browning of fruits and is present in mushrooms, apples and potatos. This enzyme catalyzes phenol oxidation with molecular oxygen through two distinct reactions: the ortho-hydroxylation of phenol producing cathecols and its dehydrogenation producing quinones. Quinones are extremely 
unstable in aqueous solutions, reacting nonenzymatically to produce brownish insoluble polymers (Duckworth and Coleman, 1970). These polymers can be removed from solution through many process such as adsorption, precipitation and flotation.

Chitosan, a polycationic polymer produced by chitin deacetilation, is commonly used as adsorbent or coagulant. Wada et al. (1995) and Gangidoust et al. (1996) showed in their research that it is more effective to use chitosan in an acetic solution as coagulant agent than to use its flakes as adsorbent. In this way smaller quantities of the product are required in order to remove suspended materials.

The present work addressed the efficiency of enzymatic treatment using tyrosinase (either for pretreatment or polishing with chitosan as a coagulant) in phenol removal together to conventional aerobic biological treatment.

\section{MATERIALS AND METHODS}

All reagents used were of analytical grade. Chitosan was from Aldrich; 4-aminoantipirin (4AAP), from Sigma; 1-tyrosine; $\mathrm{K}_{3} \mathrm{Fe}(\mathrm{CN})_{6}$ and acetone, from Vetec; and phenol, $\mathrm{K}_{2} \mathrm{HPO}_{4}$, urea and acetic acid, from Reagen. The mushrooms used (Agaricus bispora) were bought at a local market.

\section{Tyrosinase Extraction}

Mushrooms were triturated with acetone and then filtrated; the resulting cake was frozen. Afterwards, the frozen cake was resuspended in distilled water and filtrated again to obtain enzymatic extract containing tyrosinase (Atlow et al., 1984). The activity of extracted tyrosinase was from 2,000 to 8,800 U. $\mathrm{mL}^{-1}$, depending on the lot of mushrooms used.

\section{Tyrosinase Activity}

One activity unit was defined as the amount of enzyme that increased absorbance $0.001(\lambda=280$ $\mathrm{nm})$ per minute, in a $3 \mathrm{~mL}$ reaction medium containing L-tyrosine $(0.5 \mathrm{mM})$ in potassium phosphate buffer $(0.05 \mathrm{M}) \mathrm{pH} 6.5$ and a temperature of $25^{\circ} \mathrm{C}$.

\section{Polishing of Phenolic Solutions}

Phenol removal catalyzed by tyrosinase was initially tested in experiments using buffer solutions (potassium phosphate $0.05 \mathrm{M}, \mathrm{pH} 6.5$ ) containing 20 $\mathrm{mg} . \mathrm{L}^{-1}$ of phenol. Reactions were performed at room temperature in $200 \mathrm{~mL}$ aerated and magnetically stirred reactors. The working volume was 50 or 100 $\mathrm{mL}$, and samples of 2 to $3 \mathrm{~mL}$ were taken periodically. Reactions were stopped by adding $0.1 \mathrm{~mL}$ of $\mathrm{H}_{3} \mathrm{PO}_{4} \quad 8.5 \% \quad$ w/v. Tyrosinase concentrations tested were of $20,30,46$ and 100 U.mL ${ }^{-1}$ and chitosan concentrations were $0 ; 25 ; 75$ e $100 \mathrm{mg} . \mathrm{L}^{-1}$. Phenol concentration was analyzed at the beginning and after 20 hours reaction.

Chitosan solution $(0.5 \% \mathrm{w} / \mathrm{v})$ was prepared by dissolving it in acetic acid $0.5 \% \mathrm{v} / \mathrm{v}$.

\section{Enzymatic Pretreatment}

Enzymatic pretreatment was conducted in aerated and magnetically stirred beakers for two hours using $250 \mathrm{~mL}$ of effluent and $20 \mathrm{U} \cdot \mathrm{mL}^{-1}$ of enzymatic extract. Initial $\mathrm{pH}$ was 6 . Occasionally, initial $\mathrm{pH}$ was lower than 6 and was adjusted to $6.0-6.5$ with $\mathrm{NaOH} 0.1 \mathrm{~N}$.

After enzymatic pr-treatment, the effluent was fed to biological reactor which operated under a batch time of 24 hours.

\section{Biological Treatment}

The bioreactor used was a $600 \mathrm{~mL}$ beaker, aerated with porous material and mechanically stirred.

The sludge used had been collected at the Wastewater Treatment Station of Ilha do Governador (ETIG-Cedae). Sludge was acclimatized in 24 hours batches, in which the ratio between synthetic effluent and municipal wastewater was gradually increased until it reached $100 \%$ synthetic wastewater containing $200 \mathrm{mg} . \mathrm{L}^{-1}$ of phenol. Phenol content was further increased, and when it reached $360 \mathrm{mg} . \mathrm{L}^{-1}$ $\left(75^{\text {th }}\right.$ acclimatization day) batch time was increased to 48 hours. Acclimatization continued until the phenol concentration in the feeding medium was $420 \mathrm{mg} \cdot \mathrm{L}^{-1}$. After the $119^{\text {th }}$ day of acclimatization, $25 \mathrm{~mL}$ of tap water were added to distilled water and used as diluent for the feed medium ( $250 \mathrm{~mL}$ of total volume). It was a source of micronutrients.

Synthetic wastewater was conveniently diluted from a concentrated parentsolution containing phenol, urea and phosphate (COD:N:P 100:5:1), according to desired phenol concentration. The $\mathrm{pH}$ of the feeding medium was set to 7 with $\mathrm{NaOH} 1.0 \mathrm{~N}$ or $\mathrm{H}_{2} \mathrm{SO}_{4} 5 \%(\mathrm{v} / \mathrm{v})$. 


\section{Enzymatic Polishing of Biotreated Effluent}

Biotreated effluents in which phenol concentration was above target levels $\left(0.5 \mathrm{mg} . \mathrm{L}^{-1}\right)$ were enzymatically treated.

Reactions were conducted in a $200 \mathrm{~mL}$ aerated beaker, magnetically stirred at room temperature $\left(\mathrm{T}=25^{\circ} \mathrm{C}\right)$. The working volume used was $50 \mathrm{~mL}$. Chitosan and tyrosinase concentrations were 50 $\mathrm{mg} . \mathrm{L}^{-1}$ and $46 \mathrm{U} \cdot \mathrm{mL}^{-1}$, respectively. Periodically, samples were taken and reaction was stopped by adding $0.1 \mathrm{~mL}$ of $\mathrm{H}_{3} \mathrm{PO}_{4} 8.5 \% \mathrm{w} / \mathrm{v}$.

A blank reaction corresponding to each experiment was carried out using the same biotreated effluent under equal stirring and aeration conditions, but without chitosan and tyrosinase.

\section{Analytical Methods}

Phenol analysis was done according to the direct colorimetric method in Standard Methods (APHA, 1992).

Color was determined spectrophotometrically at $\lambda$ $=400 \mathrm{~nm}$ after filtrate samples through Whatman $\mathrm{n}^{\mathrm{o}}$ 4 filter paper (Wada et al., 1995).

Chemical oxygen demand (COD) was determined in Hach equipment by the closed reflux colorimetric method (APHA, 1992).

Total suspended solids (TSS) and volatile suspended solids (VSS) concentrations of sludge were determined according to the standard proceedings established in Standard Methods (APHA, 1992).

Volumetric sludge index (VSI) was defined as the volume occupied by $1 \mathrm{~g}$ of active sludge (dry weight) after settling for 30 minutes, accordingly to Standard Methods (APHA, 1992)

\section{RESULTS AND DISCUSSION}

The effectiveness of using crude tyrosinase extracted from mushrooms together with chitosan solution for enzymatic polishing of phenolic effluents was first studied in experiments using phenol in buffer solutions. Reaction time was 20 hours in order to guarantee complete phenol reaction and precipitation of brownish products. Although enzymatic reaction is relatively fast, polymer precipitation and/or adsorption is much slower and is noticeable only after 7 hours reaction. Figure 1 shows the phenol removal achieved by oxidation catalyzed by tyrosinase along with precipitation with acetic chitosan solution. The best results were achieved using $50 \mathrm{mg} . \mathrm{L}^{-1}$ of chitosan. Higher chitosan concentrations were deleterious to process, probably due to interference with enzymatic activity or to complexing with the enzyme. Color removal in those experiments is shown in Figure 2. Chitosan solution contributed to reducing color in the phenolic solution, which was enzymatically treated. The best results were achieved (Abs $400 \mathrm{~nm}$ less than 0.2) by using at least $50 \mathrm{mg} . \mathrm{L}^{-1}$ chitosan with up to $46 \mathrm{U} \cdot \mathrm{mL}^{-}$ ${ }^{1}$ of tyrosinase. The enzyme solution was dark and higher concentrations of tyrosinase increased color. Excess chitosan also negatively affected color as it increased turbidy.

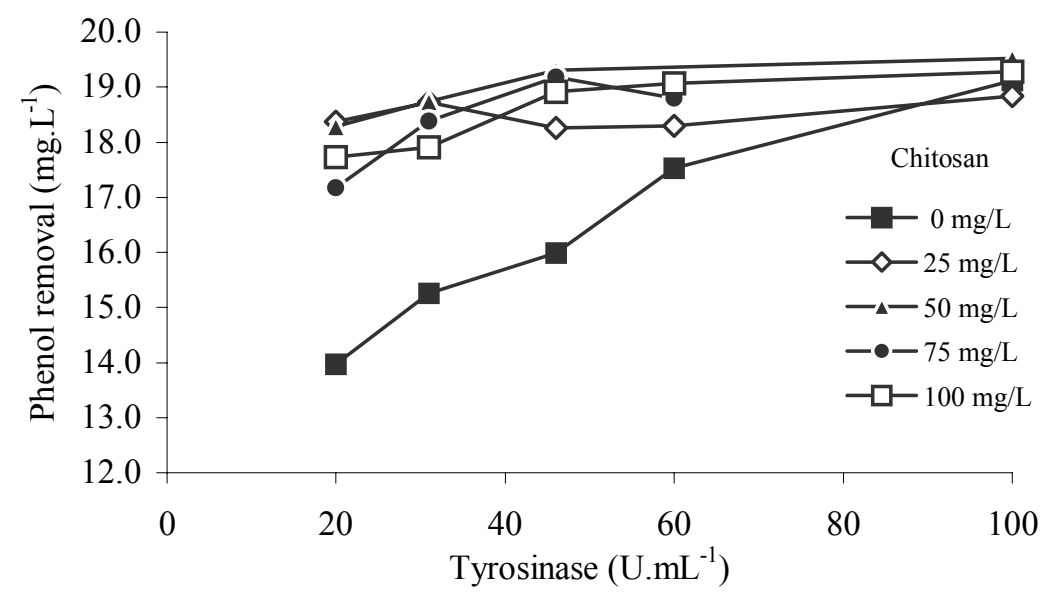

Figure 1: Phenol removal by crude tyrosinase together with acetic chitosan solution (reaction time of 20 hours). 


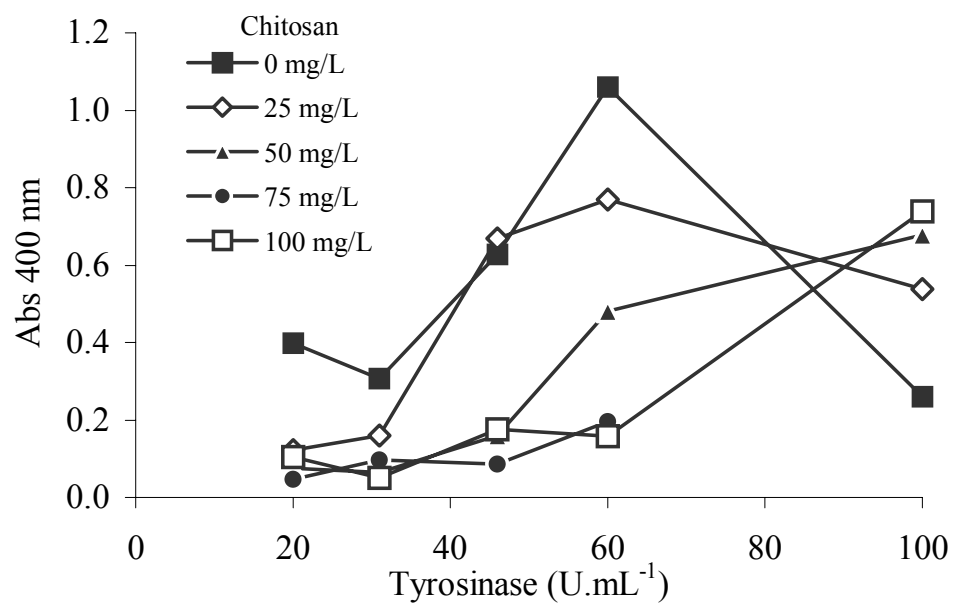

Figure 2: Evaluation of color in reactional media with buffered phenol solution, crude tyrosinase and acetic chitosan solution (reaction time of 20 hours).

A kinetic profile of enzymatic phenol removal was performed under two different sets of conditions (46 U.mL $\mathrm{m}^{-1}$ of tyrosinase and $50 \mathrm{mg} . \mathrm{L}^{-1}$ of chitosan; $60 \mathrm{U} \cdot \mathrm{mL}^{-1}$ of tyrosinase and $100 \mathrm{mg} . \mathrm{L}^{-1}$ of chitosan). It was verified that most of the phenol is removed during the first 5 hours (Figure 3) and a small amount of additional removal occurs thereafter, probably due to physicochemical phenomena (volatilization and adsorption). Removal of up to $98 \%$ of the phenol was achieved, producing final solutions with only $0.4 \mathrm{mg} . \mathrm{L}^{-1}$ of phenols, therefore below target limits. Higher tyrosinase and chitosan concentratrions were not reflected in kinetic improvements of process.

The sludge collected at ETIG-Cedae had $1090 \mathrm{mg}$ of TSS.L $\mathrm{L}^{-1}$ and $229 \mathrm{~mL} . \mathrm{g}^{-1}$ of VSI. It was necessary to concentrate the sludge before inoculating it in the reactor. The initial sludge concentration in the bioreactor was $2000 \mathrm{mg}$ of VSS.L ${ }^{-1}$.

Figures 4 and 5 show microbial acclimatization to effluent containing phenol. The proportion of synthetic effluent to sewage was augmented gradually, what increased COD of the feeding solution. Despite of that, COD removal efficiency also improved, reaching about $80 \%$ by the fourth week of operation. COD removal remained between 90 and $97 \%$ and phenol degradation efficiency was $99 \%$ in the first 60 days of operation, when phenol concentration in the feeding solution was up to 200 mg. $\mathrm{L}^{-1}$.

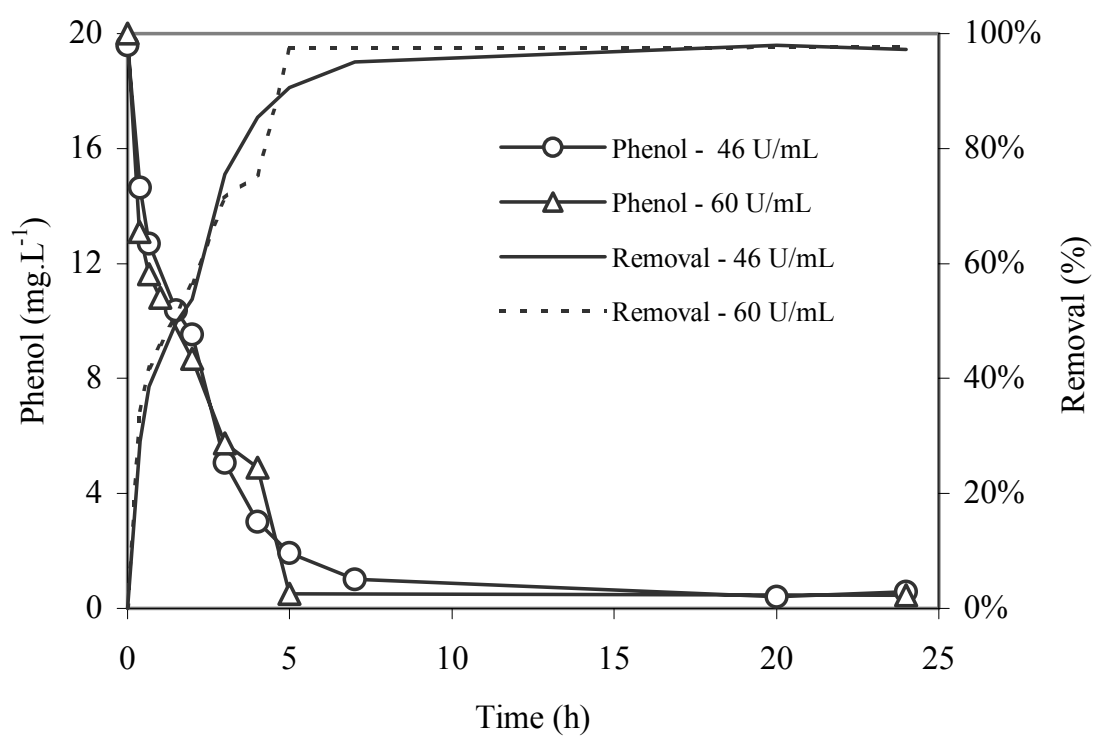

Figure 3: Kinetic profile of phenol removal using $46 \mathrm{U} \cdot \mathrm{mL}^{-1}$ of tyrosinase and 50mg. $\mathrm{L}^{-1}$ of chitosan or $60 \mathrm{U} \cdot \mathrm{mL}^{-1}$ of tyrosinase and $100 \mathrm{mg} . \mathrm{L}^{-1}$ of chitosan. 


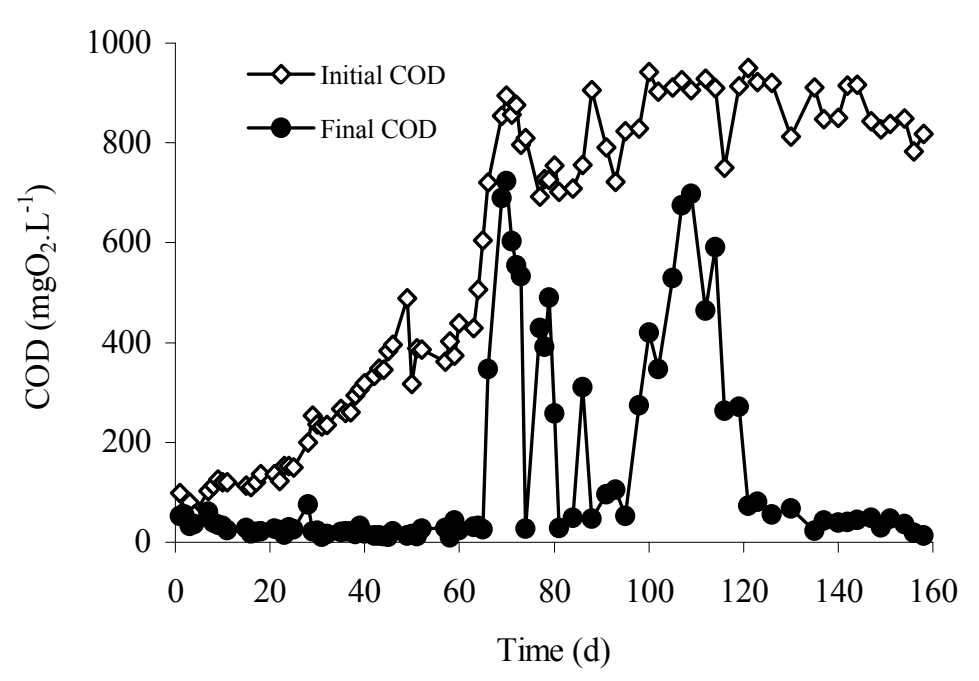

Figura 4: COD removal during microbial acclimatization.

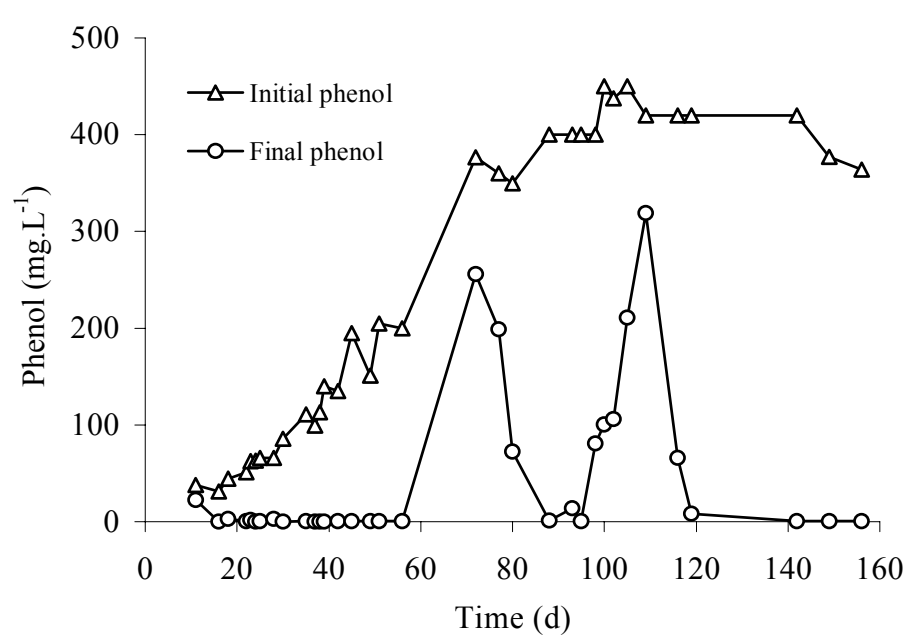

Figura 5: Phenol removal during microbial aclimatization.

An increase in phenol concentration in the feeding solution from 200 to $400 \mathrm{mg} . \mathrm{L}^{-1}$ over a short period of time dramatically reduced treatment quality. COD removal efficiency fell to only $26 \%$ and phenol removal was reduced to $32 \%$.

In order to overcome this problem, phenol concentration in the feeding solution was reduced to $360 \mathrm{mg} . \mathrm{L}^{-1}$ until operation of the bioreactor returned to former patterns. In spite of this, final effluent quality was not improved. Therefore batch operation time was increased from 24 to 48 hours. This batch operation time was mantained until the end of acclimatization period.

A few days after the bioreactor had started operating in these conditions, COD removal efficiency was again over $90 \%$. Then phenol concentration in the feeding solution could be once again increased to $400 \mathrm{mg} . \mathrm{L}^{-1}$. Since this time the microorganisms were already acclimatizated to high phenol concentrations this did not caused charge shock. However, as increase in phenol concentration in the feeding solution to $450 \mathrm{mg} . \mathrm{L}^{-1}$, carried out on the $100^{\text {th }}$ acclimatization day was prejudicial to biological treatment efficiency, and it was necessary to reduce phenol concentration back down to 420 mg. $\mathrm{L}^{-1}$. Even after this alteration, reactor efficiency did not recover rapidly. As this could have been caused by the lack of mineral micronutrients essential to microorganisms, tap water was included as diluent of the parentsolution.

The operational conditions established for the bioreactor were as follows: feeding solution containing $420 \mathrm{mg} . \mathrm{L}^{-1}$ of phenol (at a 1:9 ratio of tap to distilled water as diluent) and a batch time of 48 hours. Bioreactor operation was mantained in this condition for an additional 30 days, and medium values of COD and phenol removal were $95.7 \%$ and $99.9 \%$, respectively.

Experiments of enzymatic polishing were performed with samples obtained during 
acclimatization whose phenol concentration was above the legal discharge limits $\left(0.5 \mathrm{mg} . \mathrm{L}^{-1}\right)$. Tyrosinase and chitosan concentrations used were first optimized in experiments with buffered phenol solutions (20 mg. $\left.\mathrm{L}^{-1}\right)$ (see Figures 1 and 2).

Figure 6 shows the results for average phenol removal, obtained in polishing tests. It can be observed that maximum phenol removal (75\%) occurred when the initial phenol concentration in the enzymatic reactor was equal to or less than $20 \mathrm{mg} . \mathrm{L}^{-1}$. This result was already expected as enzyme and chitosan concentrations had been optimized for this phenol concentration.

The results achieved in synthetic media (up to 98\% phenol removal) during optimization of reaction conditions were better than those obtained with biotreated effluent. This was probably due to the fact that synthetic effluent is an ideal medium, without microbial metabolites and other compounds that could cause enzymatic inhibition or compete with phenol.

The highest removal efficiencies, in terms of quantity of phenol removed, were achieved when treating effluents with high initial phenol concentrations (phenol removal of $92 \mathrm{mg} . \mathrm{L}^{-1}$ in the experiment with an initial phenol concentration of $\left.146 \mathrm{mg} . \mathrm{L}^{-1}\right)$.

Enzymatic inhibition caused by biotreated effluent led to an innovative strategy: enzymatic pretreatment of effluent. The aim of pretreatment was to reduce phenol concentration in the bioreactor feeding solution, which could diminish operational batch time and improve removal efficiency.

Although biomass growth had not been quantified, the fast increase in sludge volume could be visually observed as more biodegradable substrates were introduced (proteins contained in enzymatic solution). During conventional biological treatment, only that biomass which was arrested in the effluent discharges of the bioreactor was removed. After enzymatic pretreatment started, biomass was drained daily and a maximum sludge volume of $50 \mathrm{~mL}$ was allowed.

Residence time for biological treatment preceded by enzymatic pretreatment was reduced from 48 hours to 24 hours, since initial phenol concentration was lower (on average $283 \mathrm{mg} . \mathrm{L}^{-1}$ ). Figures 7 and 8 show results obtained in the biological treatment of enzymatically pretreated effluents.

Pretreatment with enzymatic solutions increased initial COD in 18 to $52 \%$, as a consequence of higher levels of organic matter added. Initial COD could not remain constant as quantity of enzyme was varied due to alterations in its activity. During pretreatment, $20 \mathrm{U} \cdot \mathrm{mL}^{-1}$ of tyrosinase were added, which meant adding volumes of enzymatic solution from 1.27 to $1.68 \mathrm{~mL}$. The most significant alterations of COD intake occurred after the $15^{\text {th }}$ day of operation, when enzymatic solution was changed and average the COD in the feed changed from 1013 $\mathrm{mgO}_{2} \cdot \mathrm{L}^{-1}$ to $1300 \mathrm{mgO}_{2} \cdot \mathrm{L}^{-1}$.

The enzymatically pretreated and biotreated effluent had average COD and phenol contents of $151 \mathrm{mgO}_{2} . \mathrm{L}^{-1}$ and $1.0 \mathrm{mg} . \mathrm{L}^{-1}$, respectively. These values are higher than those obtained in conventional biological treatment (average COD and phenol content at the end of batches were $35 \mathrm{mgO}_{2} \cdot \mathrm{L}^{-1}$ and $0.4 \mathrm{mg} . \mathrm{L}^{-1}$, respectively). This result was probably a consequence of difference between biomass aclimatization periods, becaused acclimatization to synthetic wastewater exceeded 100 days in conventional biological treatment, and was much shorter when effluent was enzymatically pretreated.

Enzymatic pretreatment of phenolic effluent produced brownish products (originating in quinone polymerization) that were not degraded by subsequent biological treatment. Additional polishing steps would be necessary to remove effluent color.

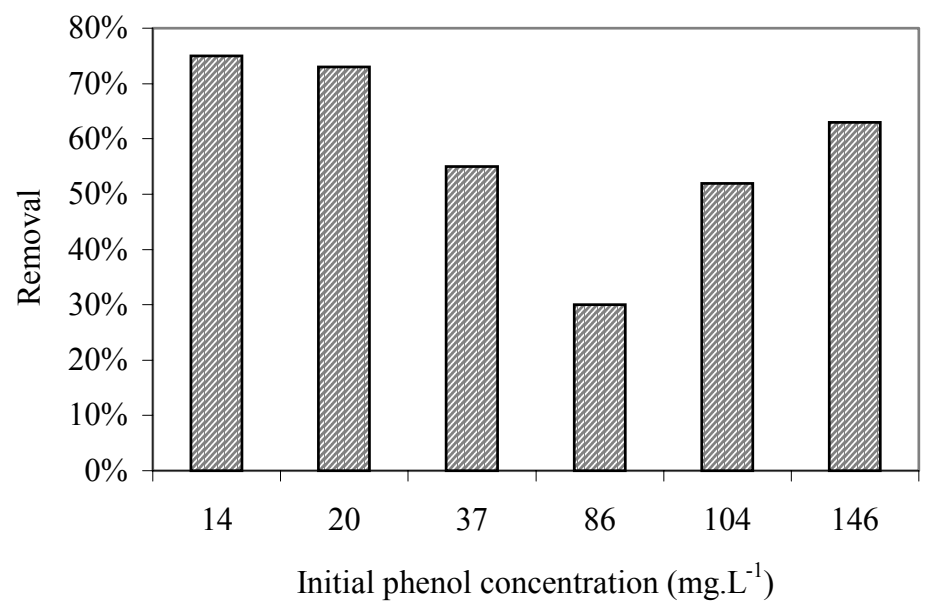

Figura 6: Phenol removal efficiency (values are the average of duplicates) after enzymatic polishing of biotreated effluent with $46 \mathrm{U} \cdot \mathrm{mL}^{-1}$ of tyrosinase and $50 \mathrm{mg} . \mathrm{L}^{-1}$ of chitosan reaction time was 4 hours. 


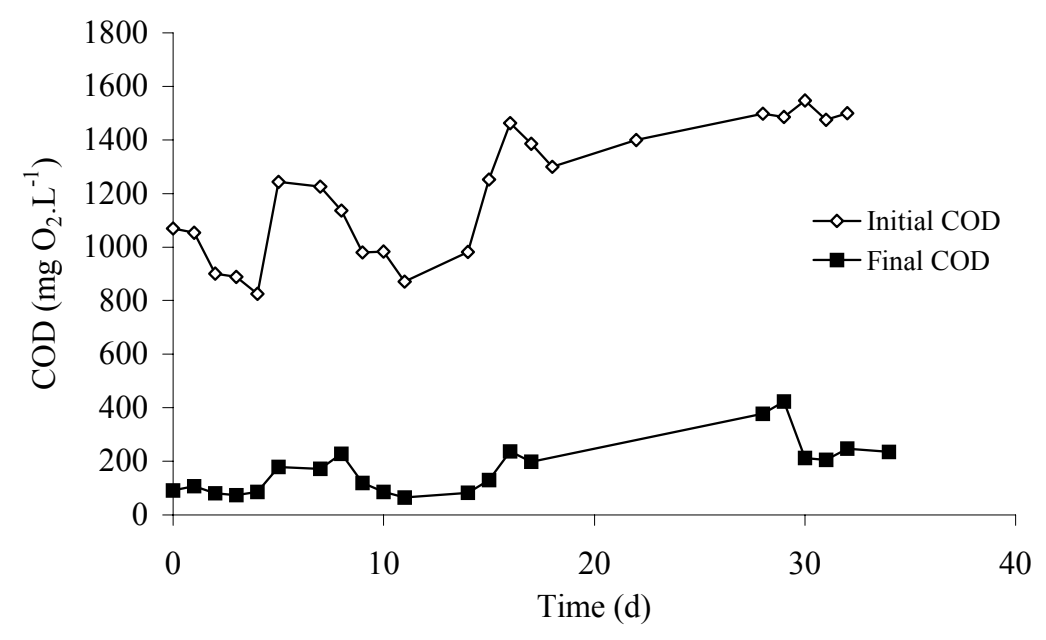

Figure 7: COD removal achieved through biological treatment of enzymatically pretreated effluent.

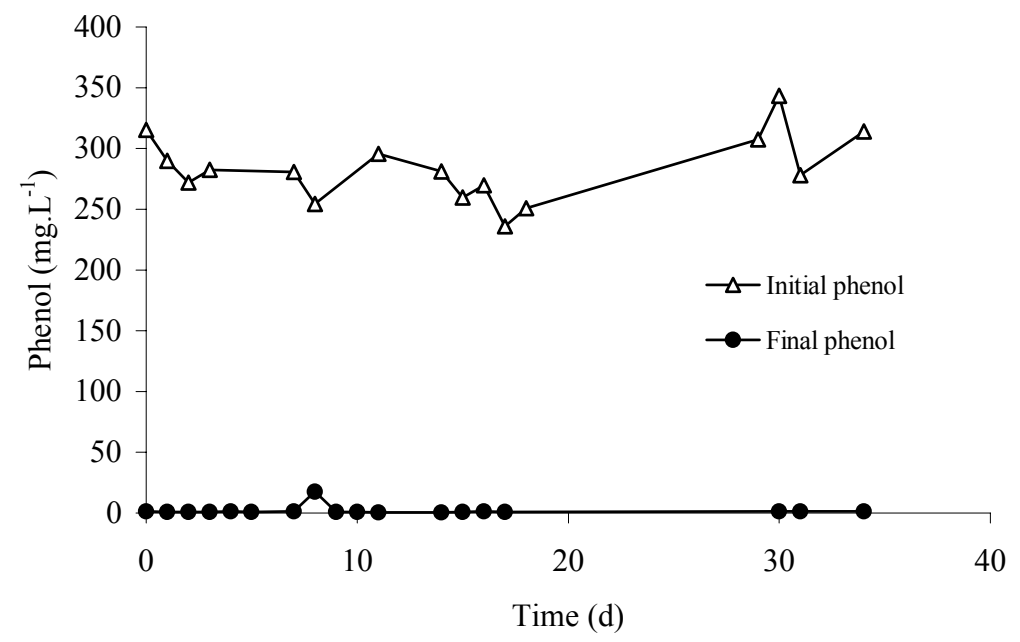

Figure 8: Phenol removal through biological treatment of enzymatically pretreated effluent .

\section{CONCLUSION}

The best results for the experiments on phenol oxidation in buffered solution were achieved using $46 \mathrm{U} . \mathrm{mL}^{-1}$ of tyrosinase and $50 \mathrm{mg} . \mathrm{L}^{-1}$ of chitosan; these experiments produced final effluent containing only $0.4 \mathrm{mg} . \mathrm{L}^{-1}$ of phenol after 20 hours of reaction.

Conventional biological treatment is a suitable process for degrading phenol and is highly efficient in removal of this pollutant. However, alterations in feeding concentration may affect biological treatment, diminishing final effluent quality. When this happens, it is necessary to adopt complementary procedures to bring effluent quality within legal discharge limits.
When the bioreactor was not operating properly, enzymatic polishing of biotreated effluent caused a considerable reduction in phenol content, althought the legal discharge limit was not achieved.

Enzymatic pretreatment may be a useful tool for reducing residence time in biological reactors and preventing stress caused by increasing pollutant content. Nevertheless, color generated by enzymatic reaction and COD content increases in bioreactor intake make this technology less interesting for wastewater treatment. Use of immobilized tyrosinase through development of new techniques that stabilizes it and remove generated quinones may encourage combined biological/enzymatic treatments to degrade phenols, specially in emergency situations. 


\section{ACKNOWLEDGEMENT}

The financial support of CAPES, FUJB and FAPERJ is gratefully acknowledge.

\section{REFERENCES}

APHA, Standard Methods for the Examination of Water and Wastewater, 18th ed., American Public Health Association, Maryland (1992).

Atlow, S.C., Bonadonna-Aparo, L., Klibanov, A.M., Dephenolization of Industrial Wastewaters Catalyzed by Polyphenol Oxidase, Biotechnol. Bioeng., XXVI, 599-603 (1984).

Bevilaqua, J.V., Utilização de Tirosinase de Agaricus bispora no Tratamento de Efluentes Contendo Fenóis, M.Sc. Thesis, COPPE/UFRJ, Rio de Janeiro (2000).

CONAMA, Resolução CONAMA No. 20, de 18 de Junho de 1986 §art.21, in: Resoluções do CONAMA; 1984 a 1990, 3rd ed., IBAMA,
Brasília (1991).

Duckworth, H, Coleman, J.E., Physicochemical and Kinetic Properties of Mushroom Tyrosinase, J. Biol. Chem., 245, 1613-1625, (1970).

Flurkey, W.H., Identification of Tyrosinase in Mushrooms by Isoeletric Focusing, J. Food Sci., 5693-95 (1991).

Gangidoust, H., Tatsumi, K. Wada, S., Kawase, M., Role of Peroxidase and Chitosan in Removing Chorophenols from Aqueous Solutions, Wat. Sci. Tech., 34, 151-159 (1996).

Karam, J., Nicel, J.A., Potential Applications of Enzymes in Waste Treatment, J. Chem. Tech. Biotechnol., 69, 141-153 (1997).

U.S. EPA, Treatability Manual, vol. I - Treatability Data, U. S. Environmental Protection Agency, Washington, D.C. (1980).

Wada, S., Ichikawa, H., Tatsumi, K., Removal of Phenols and Aromatic Amines from Wastewater by a Combination Treatment with Tyrosinase and a Coagulant, Biotechnol. Bioeng., 45, 304-309 (1995). 